\title{
変形性股関節症に対する寛骨臼回転骨切り術
}

—とくに外転筋力について——

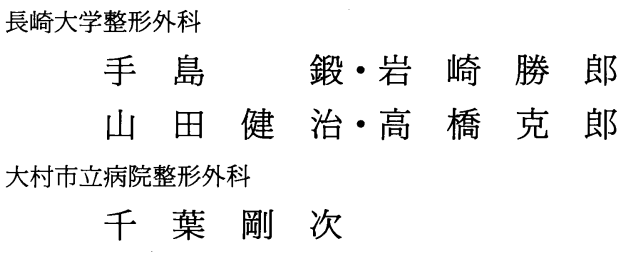

\section{An Analysis of the Isometric Muscle Force \\ of the Hip Abductor after Rotational Acetabular Osteotomy}

by

\section{Kitau Teshima, Katsuro Iwasaki, Kenji Yamada and Katsuro Takahashi}

Department of Orthopaedic Surgery, Nagasaki University School of Medicine Nagasaki, Japan

\begin{abstract}
We measured isometric muscle force of the hip abductor to evaluate the influences of the surgery to the hip.

Measurement was done on eleven patients with osteoarthritic hip treated by rotational acetabular osteotomy, using a new device of our own design pre- and postoperatively. The force was measured at four different degree in adduction-abduction position such as fifteen degrees in adduction, neutral, fifteen and thirty degrees in abduction. An abduction force was evaluated on maximum value and durability.

Maximum value within six months after operation shwed less than that of preoperative one at any position, and they recovered to preoperative values over six months after operation at fifteen degrees adducted and neutral position. On the other hand at fifteen degrees and thirty degrees abducted posotion did not. Durability was increased within six months after operation, and then the variation between each position became small over six months after operation.
\end{abstract}

\section{はじめに}

変形性股関節症に対する治療として寬骨臼回転骨切 り術 (RAO)（図 1 ）は臼蓋形成不全の改善と骨頭の内 方化を達成し得る手術の 1 つである. しかし関節包付 着部を大きく展開するために中殿筋，小殿筋など股関 節の重要な外転筋を腸骨付着部から剝離しなければな らず, 外転筋力の低下が危惧される. 今回我々は RAO 後の股関節外転筋力の回復状況を知るために我々が新 たに開発した方法で手術前後での股関節外転筋力を評
価し検討を加えた。

\section{対象と方 法}

対象は長崎大学で RAO を行った変形性股関節症患 者のうち術前及び術後に経時的に筋力の計測ができた 11 例 11 股で, 全例女性であった。手術時年令は 16 才 から 50 才で平均 38.3 才であった。手術時の変股症の 進行度は初期股関節症 7 例, 進行期股関節症 4 例であ つた，手術はすべて田川らの方法に準じて行った，後 療法は原則として術後 3 週間後より外転筋力強化訓練 


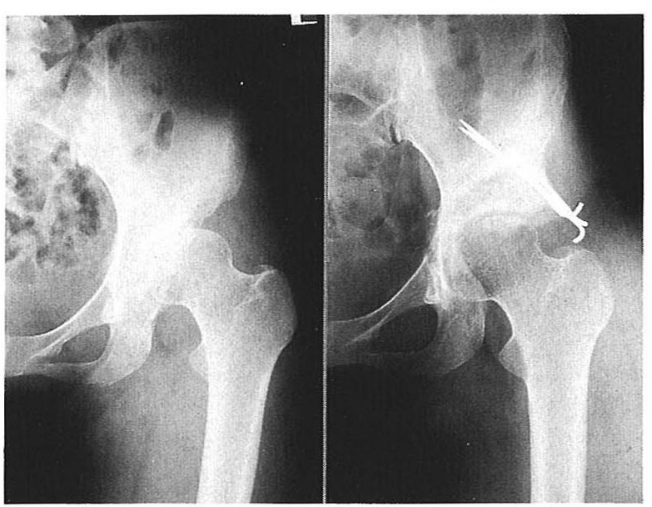

図 1. 寛骨臼回転骨切り術：骨頭の被覆と内方化が達 成されている.

表 1. 我々の後療法プログラム: 術後 8 週間で部分荷重を 開始し, 約 20 週間で全荷重を許可, 術後約 6 力月で 杖無しで日常生活へ復帰させている.

\begin{aligned} & \hline \hline 術後 1 日目 大腿四頭筋セッティング開始 \\ & 2 日目 CPM による ROM 訓練開始 \\ & 14 日目 2 本松葉杖による完全免荷歩行訓練開始 \\ & 3 週間後 外転筋力増強訓練開始 \\ & 8 週間後 $1 / 3$ 部分荷重歩行訓練開始 \\ & 12 週間後 $1 / 2$ 部分荷重歩行訓練開始 \\ & 16 週間後 $2 / 3$ 部分荷重歩行訓練開始 \\ & 20 週間後 全荷重での歩行訓練開始 \\ & \hline\end{aligned}

を臥位で開始し，術後 8 週間で $1 / 3$ 部分荷重を許可し 以後徐々に荷重を増加してゆき術後約 20 週間で全荷 重を許可し, 術後 6 力月で松葉杖無しで日常生活に復 帰させている(表 1 )。手術から筋力測定までの経過期 間は 17 週から 68 週, 平均 37 週であった. 筋力測定は 我々が開発し村上が先に報告した方法（図 2）に準じ て行い, 共同研究者の千葉が開発した関節外転筋評価 システムソフト (HABDUS) を用いて外転筋力を一次 減衰曲線 $\mathrm{F}=\mathrm{A} ・ \mathrm{e}^{-\mathrm{K} t}$ (図 3) へ近似した。こうする ことにより筋力の最大值は係数 $\mathrm{A}$ で，持続性は $1 / \mathrm{K}$ で表わすことができる。この方法の妥当性については すでに村上 ${ }^{2)}$ が報告しており，本研究で用いたデー夕 においても各肢位での外転筋力の減衰曲線とそれを近 似した指数関数との相関係数は内転 $15^{\circ} て ゙ 0.792$, 内 外転中間位で 0.862 , 外転 $15^{\circ}$ で 0.722 , 外転 $30^{\circ}$ で

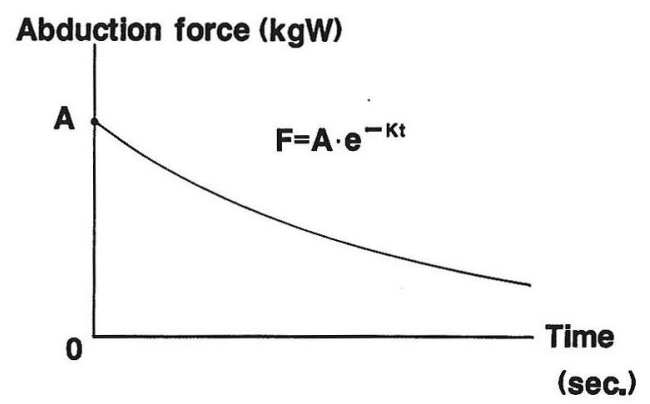

図 3、Aは最大筋力を表わし，1/Kは持続性を表わ †.
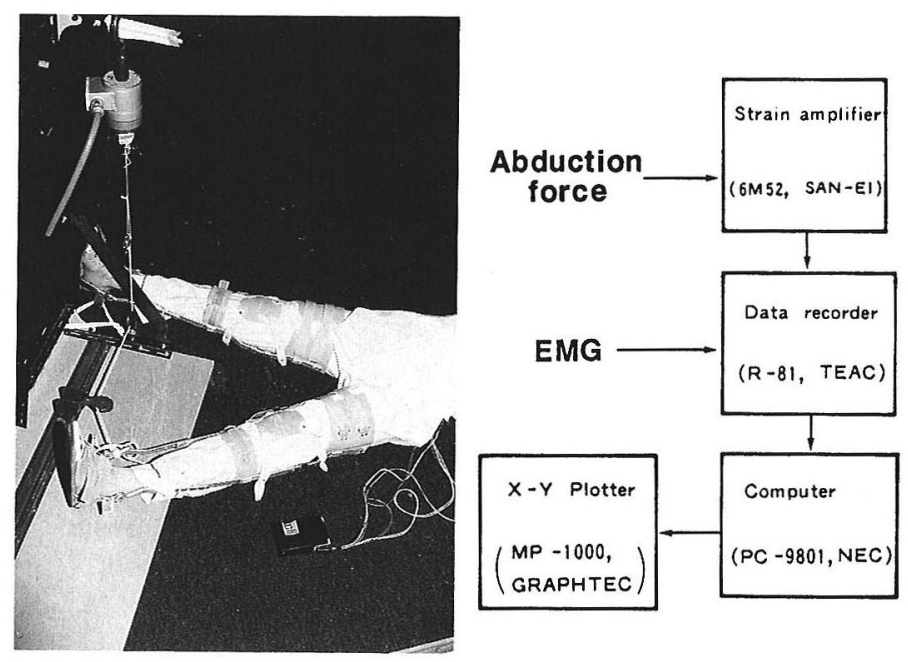

図 2. 我々が開発した外転筋測定方法 


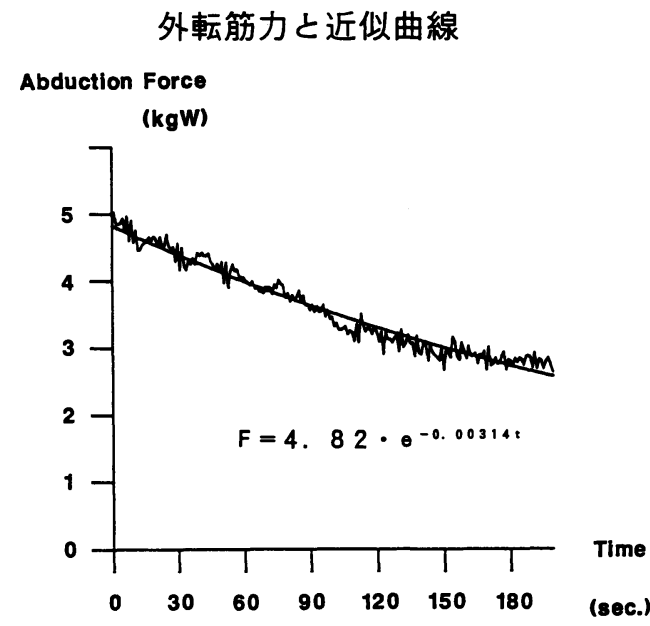

図 4.外転筋力と近似曲線

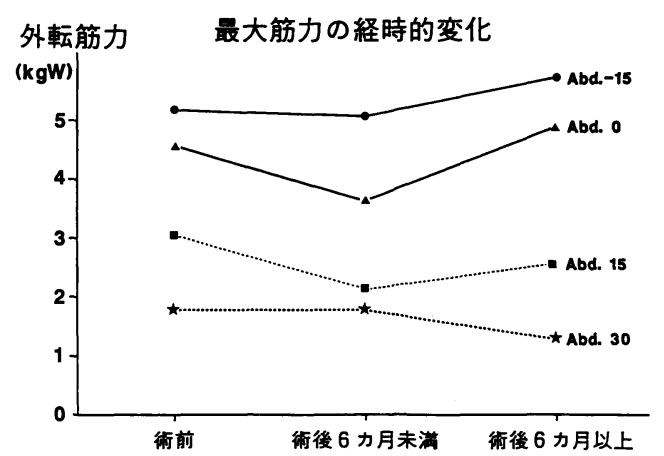

図 5 ．筋力の回復は外転角度が大きくなるほど小さい.

0.711 と高い相関を示していた.

結果

手術前後の外転筋力の最大值は内転位で大きく外転 角度が大きくなるにしたがって減少していた（図 5 ). この傾向は術後 6 力月未満, 6 力月以降でも変わるこ とはなかった. 最大筋力の経時的変化についてみると 術後 6 力月未満では筋力は術後の值まで回復していな い. 術後 6 力月以降では内転位及び内外転中間位では

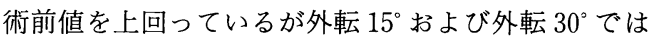
まだ回復していない。

外転筋力の持続性は術前及び術後 6 力月未満では内 転位で大きく外転角度が大きくなるにしたがって小さ くなっていた。術後 6 力月以降では肢位による持続性 の差が小さくなっていた（図6）。

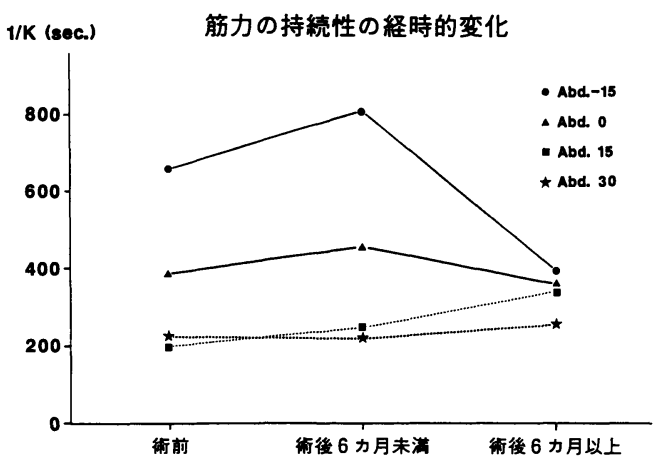

図 6 . 術後 6 力月以降では肢位による持続性の差が小 さくなっている.

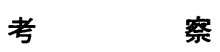

今回我々が用いた方法は外転筋の等尺性収縮時の筋 力が初期に最大值をとりしだい減衰することからこれ を指数関数を近似することによって単純化し, 最大筋 力と持続性を同時にその係数からうかがい知ろうとし たものである.

1. 最大筋力とその経時的変化について

村上 ${ }^{2)}$ は我々の方法を用いて 18 才から 28 才までの 健常男子 20 名について外転筋力の測定を行ったが, 内

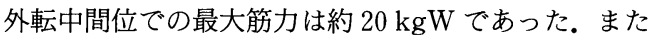
千田 ${ }^{3)}$ は用手力量計を用いて等尺性最大収縮力を下肢 筋力について測定しその経年変化について報告してい るが，その下肢外転力の測定方法は他側肢を固定し足 関節外果直上部での力を測定したものであり我々の方 法と共通している。このなかで 17 才から 20 才台の男 子の内外転中間位での最大筋力は約 $20 \mathrm{kgW}$ である こと，また女子の外転筋力は 14 才から 40 才台まであ まり変わらず男子の 50～60\%であることを示してい る、以上のことから測定機器が異なっても測定值はあ まり変わらないと仮定すると, 今回我々が対象とした 患者と同じ年代の女子の内外転中間位での最大外転力 は 10〜13 kgW であると考えられ, 今回対象とした女 性患者の 4〜 $5 \mathrm{kgW}$ という内外転中間位での最大外 転力はかなり弱いと考えざるを得ない(図 7 )。股関節 手術後の外転筋力の回復状況についての報告には, Chiari 骨盤骨切り術後の外転筋力について検討した 志波 ${ }^{4}$, RAO 後の外転筋力についての川北 ${ }^{1)}$ などがあ るが，いずれも等運動性測定機器であるサイベックス 
を用いたものである.川北は $\mathrm{RAO}$ 後の股関節外転筋 力は術後 3 力月で術前值の $65.9 \%$ まで低下しており その後徐々に回復して術後 6 力月でほほ術前の筋力ま で回復したと述べている。また志波は外転筋力のピー クトルクは術後 3 カ月目までは低下し 6 力月から 9 カ

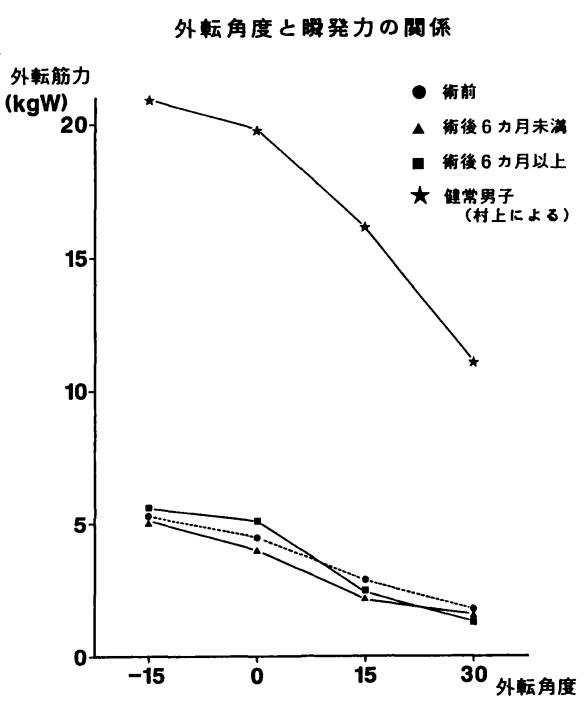

図 7 . 成人女子の正常値が成人男子の約半分と考えて も術後の筋力はかなり低い.

\section{外転角度と持続性の関係}

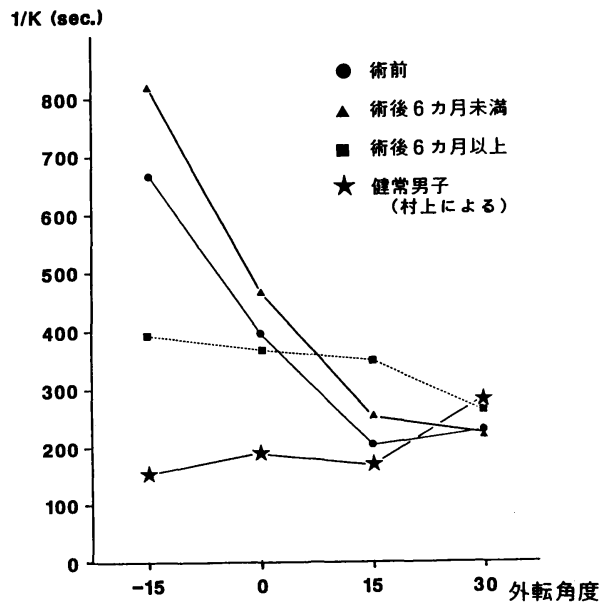

図 8. 術後 6 力月以降で外転角度と持続性の関係は正 常男子のパターンに似てくる傾向がみられる。
月目までにはほぼ術前値まで回復すると述べている。 また外転 25 度付近でのトルクの回復は遅く術後 1 年 以上を経てようやく術前值に近づくことを示している. 今回の我々の結果もこれらの報告をほほ支持するもの であった。

2. 外転筋力の持続性について

股関節外転筋力の減衰が一次減衰曲線で表現できる ことより，筋力が $1 / \mathrm{e}$ に減衰する時間 $1 / \mathrm{K}$ を持続力と してこれまでの漠然としたものではなく明かな数值と して示すことができる. 図 8 は今回のデー夕に村上が 既に報告したデー夕を加えたものであるが術前，術後 とも村上の結果とは逆の，つまり外転角度が増加する と持続力が低下寸る傾向を示している．しかし術後 6 カ月以降でこの傾向がやや薄れ正常男子のパターンに 近づいてきていることは興味深いことである. RAO 後に外転筋に起こり得る変化としては筋のボリューム の変化, 筋長の変化, 赤筋と白筋の活動性の変化など が考えられるが今回の研究ではこれを明らかにするこ とはできなかった.

以上のことから RAO 後の外転筋力は現在の手術方 法と後療法プログラムにしたがえば最大筋力は術後 6 カ月以降に術前值までは回復し，持続性も正常のパ夕 ーンに近づく可能性があることが分かった．我々の手 術方法, 後療法システムが適切なものであるかどうか, 今後このような筋力の分析とともに筋電図学的検査も 加味して治療法を検討していきたいと考えている.

\section{結 語}

1. 寛骨臼回転骨切り術を行った 11 例に対し我々 が開発した方法を用いて等尺性収縮時の股関節外転筋 力を内転 $15^{\circ}$, 外転 $0^{\circ}, 15^{\circ}, 30^{\circ}$ の 4 肢位について計測 し, 外転筋の最大筋力と持続性で筋力を評価し, 手術 前後での変化について検討した。

2. 外転筋の最大筋力は術後 6 力月まではいずれの 肢位でも術前値より低下していたが 6 力月以降回復す る傾向がみられた。

3. 術後 6 力月以降での外転筋力の回復の程度は外 転角度が小さいほど大きい傾向を示していた。

4. 外転筋の持続性は術前及び術後 6 力月未満では 内転位で大きく外転位で小さい值を示したが術後 6 力 月以降ではその差が小さくなり正常のパターンに近づ く傾向を示していた。 


\section{参 考 文 献}

1）川北 哲也：寛骨臼回転骨切り術施行例における股 関節外転筋力回復の検討, Hip Joint, $11: 241-244$, 1989.

2） 村上 潔：股関節等尺性外転時の外転筋力，一新たな 評価法と筋電図学的解析一, 日整会誌, 63(11)：13581367, 1989.

3）千田益生：下肢筋力の経年変化, リ八医学, $24: 85^{-}$ 91, 1987.

4）志波直人他：Chiari 骨盤骨切り術後の外転筋力 (Cybex による測定值とコンピューターシミレーショ ンによる外転運動の解析), 整と災 38 : (2) 474-479, 1989.
質 問鹿児島市立病院 谷口 良康

術後体重負荷について。

全荷重は術後どの位の期間から開始されますか. 先 生のご研究では, 外転筋の筋力は術後 6 力月から徐々 に回復して来るとのことで, その辺りの兼ね合いを教 示下さい.

解 答長崎大学 手島 鍛 われわれは術後 8 週で部分荷重を開始. 約 20 週で全 荷重を許可しているが，荷重の時期が早すぎたための トラブルはない. 筋力の回復に荷重歩行は影響を与え ると考えている。 